unnecessary for salt accumulation per se. It is in these operations that undue weight seems to have been given to certain special features, not applicable to cells in general, of what is after all an obscure organism.

Lastly, there seems grave danger that the admittedly ingenious and extensive work devoted to models ${ }^{3}$ may divert attention from the fundamental facts that, not only are they far removed from physiological reality, but also that the very principles upon which they are based are such that judgment must be reserved concerning their applicability to the general problem of salt absorption in vivo.

Osterhout, W. J. V., Biol. Rev., 6, 369 ; 1931

Osterhout, W. J. V., Ergeb. Phys. und exp. Pharm., 35, 967 ; 1983. s Osterhout et al., numerous papers in $J$. Gen. Physiol., 16 and 17.
'Osterhout, W. J. V., and Stanley, W. M., J. Gen. Physiol., 15, $667 ; 1931-32$.

$727 ; 1934$.

B Jacques, A. G., and Osterhout, W. J. V., J. Gen. Physiol., 14, 301 1930.

Berry, W. E., and Steward, F. C., Ann. Bot., 48, 395 ; 1933. ${ }^{8}$ Steward, F. C., and Martin, J. C., Carn. Inst. Wash. Yearbook 33 ; 1934.

Blinks (private communication from W. J. V. Osterhout) reports that ammonium in low concentration causes the formation of spores (the so-called aplano spores) by aggregation of the protoplasm. As far as the parent cell is concerned, this represents an irreversible change which is frequently caused by injury-mechanical and otherwise - as emphasised by recent experiments of Kopac at Tortugas (see Carnegie Yearbook, 1933)

${ }_{10}$ Steward, F.C., unpublished data.

${ }_{11}^{10}$ Dowle, Wm. L., Contrib. from Tortugas Lab. (In press.)

12 Steward, F. C., Carn. Inst. Wash. Yearbook, 32, 281; 1933

13 Steward, F. C., Carn. Inst. Wash. Yearbook, 32, 281 ; 1933. Berkeley, Cal.; 1934 . Berkeley, Cal.; 1934.

576 ; 1932. Steward, F. C., Protoplasma, 17, 436 ; 1932. 18, 208 ; 1933.

\title{
Conference on Industrial Physics
}

$\mathrm{T}$ HE first Conference on Industrial Physics to be held in Great Britain took place in Manchester under the auspices of the Institute of Physics on March 28-30. The subject chosen for the Conference was "Vacuum Devices in Research and Industry", and its chief object was to direct attention to the important part which physics and physicists can and do play in modern industrial life. Nearly six hundred people registered as members of the Conference, of which about a hundred were members of the Institute. The majority of the others were engaged in Government and industrial research laboratories and works, some coming from a considerable distance to attend the meetings. The outstanding success of this new venture of the Institute of Physics has demonstrated beyond all possible doubt that there exists a very large number of men who are engaged in applying physics to the solution of industrial problems, in addition to many who are employing its methods for industrial work of a more routine character. One of the objects of the Institute is to provide facilities for the interchange of ideas among those engaged on industrial physics problems by means of meetings and special journals. Many propositions towards the achievement of these objects will doubtless come to earlier fruition as a direct result of this Conference.

The sessions were held in the University of Manchester. The Conference was formally opened by Sir William Clare Lees and the Vice-Chancellor, and was presided over by Prof. W. L. Bragg. The lectures were all informal in character, and consequently they are not being published; each lecture was followed by a useful discussion. The titles and lecturers were as follows: "Modern Electrical Illuminating Devices" by Mr. J. W. Ryde, of the General Electric Co, Ltd.; "Applications of Photocells" by $\mathrm{Mr}$. T. M. C. Lance, of Messrs. Baird Television Ltd., and Mr. R. C. Walker, of the General Electric Co. Ltd.; "The Cathode Ray Oscillograph in Research and Industry" by Mr. L. H. Bedford, of Messrs. A. C. Cossor Ltd.; "Recent Applications of Mercury Vapour Rectifiers and Thyratrons" by Mr. L. J. Davies and Mr. A. L. Whiteley, of the British Thomson-Houston Co. Ltd. ; "High Tension Vacuum Tube Devices in Research and Industry" by Dr. J. D. Cockeroft, of the Cavendish Laboratory, Cambridge ; "X-rays in Industry" by Dr. G. Shearer, of the National Physical Laboratory. It was interesting to record that, almost without exception, those who took a leading part in the various activities of the Conference, including the lecturers, were quite young men. The Organising Committee also received considerable commendation for its care in the selection of the lecturers, who were in each instance associated with industrial practice; the Committee preferred to extend the invitations to lecture to such men rather than to distinguished pioneers of the devices who, it was felt, would be more familiar with them in the laboratory stage, as distinet from their adapta. tion for industrial purposes.

On March 29 the members of the Conference spent the afternoon at the research laboratories and works of Messrs. Metropolitan-Vickers Electrical Co. Ltd., and the next day visits were paid to the Shirley Institute of the British Cotton Industry Research Association, and to the Post Office Telephones.

An exhibition of apparatus, instruments and books cognate to the subject of the Conference was held in the laboratories of the University, in which twenty firms and research organisations took part, and in addition some of the important work which is being carried on in the physical laboratories of the University was demonstrated. A special section intended to exemplify the multifarious uses and utilitarian value of vacuum devices was a feature of the exhibition, and aroused great interest. The specific function of the whole exhibition was to demonstrate that apparatus such as the cathode ray tube and the photocell, for example, are now utilised in devices which are practically fool-proof and can be used as tools in all manner of manufacturing processes. Unlike other exhibitions, it was not so much concerned with demonstrating the underlying physical principles of instruments or details of their mechanism, but rather with the fact that the devices shown were not mere scientific toys that had been brought from the laboratory and disguised, but that these devices were real and necessary industrial tools, which the more enterprising manufacturers are already employing. A limited number of copies of the catalogue of the exhibition is still available from the Institute of Physics, London, S.W.7 (1s. $3 d$. post free).

On Saturday morning some 65 parties from local schools visited the exhibition, and in the afternoon and evening it was thrown open to the public. It is estimated that 3,500 people visited the exhibition during the three days.

Prof. W. L. Bragg broadcast a talk about the 
Conference and exhibition on the evening of March 29 and it also received considerable attention from the Press. On Friday evening, March 29, Mr. R. A. Watson Watt delivered a public lecture, which was attended by about 350 people, on "Cathode Ray Tubes in Industry". The lecture was given in the Great Hall of the College of Technology. It is hoped, in these ways, to bring to the notice of all, the great possibilities of existing inventions and scientific knowledge of a physical character, and the important part which these play in everyday life.

The social events included a Conference dinner in the College of Technology, at which Sir Henry G. Lyons, the president of the Institute, presided, and the guests included the Lord Mayor and the Lady Mayoress of Manchester, and a number of other distinguished persons.

The great success of this Conference renders it likely that similar conferences will be held from time to time in the future. Apart from the value of the information gained from the various lectures and discussions, as well as from the exhibition and the visits, the contacts made between physicists and those concerned with the technical developments of industry cannot but prove a fruitful source of lasting mutual benefit.

Herbert R. Lang.

\section{University Education}

T HE inaugural address of the president of the Royal Statistical Society, Prof. M. Greenwood, delivered on November 20, 1934, contained many points of interest concerning the past history and probable future of the universities of Great Britain (J. Roy. Statistical Soc., 98, 1-37, 1935).

By consideration of birth-rates, there should be a decline in numbers at the universities in $1935-36$, a recovery in 1938-9, and then, unless there is a change of policy, a steady decline. The present entrance requirements are not unduly severe; in fact, if we adopt the view of some university teachers, that failure to obtain first or second class honours shows unsuitability for university training, more than fifty per cent of the unassisted students should have been. excluded, and also 10-25 per cent of those assisted by scholarships and similar benefactions. Dr. A. Flexner, who considers that a university suitable for the present and future of the world should be concerned with the conservation and interpretation of knowledge and ideas, the search for truth, and the training of students, concedes that Oxford and Cambridge have touched the fringe of these ideals, but he finds it impossible to give even this faint praise to any other English university, least of all to London. Mr. H. G. Wells doubts whether the universities and the conceptions of education they embody are destined to any very prolonged predominance over the intellectual processes of mankind, and considers the ordinary arts course in our older universities to be "merely a wasteful prolongation of puerility". Even Dr. H. Rashdall, who cannot be accused of prejudice against the ancient universities, observes that "Universities have often had the effect of prolonging and stereotyping ideas and modes of thought for a century or more after the rest of the world has given them up".

However, Prof. Greonwood considers that Dr. Flexner's ideals are too narrow, and are capable of realisation only in small and cloistered communities like Oxford and Cambridge. For large cities such as London, he considers that the loss of intimacy may be compensated by a gain in continuity, and that requirements should be made less rigid, so as to have no chasms between matriculated and non-matricu. lated students, or between graduates and nongraduates. In the past, one supported education largely on the ground that an educated nation would be better fitted to secure advantages in the international struggle for markets. But there has been a fundamental change in economic conditions. Now that productive man-power is in excess of demand, and millions of man-hours are running to waste, higher education should be considered, not for the material or social advantage it confers, but as a path to happiness.

In the discussion that followed the address, Mr. Udny Yule deprecated some of the sterner judgments on the University of London, and suggested that it differs from the older universities in degree rather than in kind. The research worker is the evolutionary successor of the hunter and is not a being apart, stripped of emotion, an intellectual machine. On this view we can understand his psychology, his blunders, his emotions. In fact, it is impossible to draw a sharp line between the investigations of a detective and those of the best type of fellow of the Royal Society. Even a poor piece of investigation may have taught much to the investigator himself, and have given him many happy hours.

\section{University and Educational Intelligence}

London.-Dr. John Gray, since 1934 director of pathology and Lyle research scholar at Queen Mary's Hospital for the East End, has been appointed reader in morbid anatomy at the British Postgraduate Medical School, as from April 1.

On his retirement from the professorship of surgery at St. Bartholomew's Hospital Medical College at the end of the present session, the title of emeritus professor in surgery in the University will be conferred on Prof. G. E. Gask.

The Senate has approved a proposal to hold the School Examinations (General School and Higher School) overseas in and after 1936.

Str. Andrews.-The Senatus Academicus has resolved to confer honorary degrees on the following, among others : LL.D., the Right Hon. Lord Alness; Andrew Bennett, secretary of the University since 1903, and secretary of the Scottish Universities Entrance Board; Prof. C. H. Browning, Gardiner professor of bacteriology in the University of Glasgow ; Prof. A. H. Gibson, Beyer professor of engineering and director of the Whitworth Laboratories in the Victoria University of Manchester ; Sir John Boyd Orr, director of the Rowett Institute, Aberdeen.

The Fifth Quinquennial Congress of Universities of the Empire, organised by the Universities Bureau of the British Empire, will be held at Cambridge on July 13-17, 1936.

UNIVERSTrY education in the United States is breaking free from the traditional system of semesterhour credits with compulsory class attendance and teaching by textbooks. More than a hundred universities and colleges have, says Dr. McNeely of 